\title{
Can We Trust Social Capital?
}

\author{
JOEL SOBEL ${ }^{1}$
}

\section{Introduction}

S ocial CAPITAL describes circumstances in which individuals can use membership in groups and networks to secure benefits. This formulation follows the definition offered by Pierre Bourdieu (1986): "Social capital is an attribute of an individual in a social context. One can acquire social capital through purposeful actions and can transform social capital into conventional economic gains. The ability to do so, however, depends on the nature of the social obligations, connections, and networks available to you." Bourdieu does not propose an investigation of social capital using economic methodology, but his definition of social capital fits easily into strategic models of economic behavior. ${ }^{2}$

1 Department of Economics, University of California, San Diego. This essay collects ideas I have learned from others. I thank Jonathon Bendor, Mary Berry, Mary Brinton, Rachel Croson, Steve Epstein, Shoshana Grossbard-Shechtman, Martha Lampland, Mark Machina, John McMillan, Valerie Ramey, James Rauch, Ákos Róna-Tas, Arlene Saxonhouse, Gary Saxonhouse, Joel Watson, Dan Wohlfeiler, Chris Woodruff, and Kit Woolard for what they have taught me. I apologize for not understanding them better. I thank Patrice Lord for supplying the style. I began this project while a Fellow at the Center for Advanced Study in the Behavioral Sciences. I thank my classmates at the Center for conversations and encouragement and the Center for financial and clerical support. NSF funding is also gratefully acknowledged.

2 Glaeser, Laibson, and Sacerdote (2000), in a paper that constructs an economic model of social capital, give a definition remarkably close to
This formulation treats social capital as an attribute of an individual that cannot be evaluated without knowledge of the society in which the individual operates. The extent to which an individual has access to resources through social capital depends on the person's connections (whom they know, but also connections through common group membership), the strength of these connections, and the resources available to their connections. Individual choice can to some extent determine the strength and extent of connections, although not all of these connections are subject to choice.

The term social capital is not new, ${ }^{3}$ but it now appears in titles at such a high rate that it is worthwhile to think about what social capital is, what we have learned from existing studies, and what questions deserve further consideration. This essay is a reflection on social capital from the perspective of an economic theorist. The focus of the essay will be Bowling Alone by Robert Putnam, and Social Capital: A Multifaceted Perspective, a collection

Bourdieu's: "we define individual social capital as a person's social characteristics-including social skills, charisma, and the size of his Rolodexwhich enable him to reap market and non-market returns from interactions with others."

${ }^{3}$ Putnam (2000) generously identifies early uses of the term in the first chapter of his book, especially footnotes 12 and 13 (pp. 445-46); Woolcock (1998) provides an intelligent and informative overview. 
published by the World Bank and edited by Partha Dasgupta and Ismail Serageldin. ${ }^{4}$

\section{Solo Strikes: Do Empty Alleys Lead to Unsafe Streets?}

In 1995 Robert Putnam (1995) published a short article with a big idea. Putnam suggested that there has been a dramatic decline in the level of participation in group activities in the United States. He argued that the decline threatened the quality of democracy and the quality of life. The big idea stimulated a broad range of research activities: cross-national studies of social capital, research into the social capital of firms, and work investigating how trust is created in neighborhoods and in transition economies. ${ }^{5}$ Bowling Alone develops the argument put forth in the 1995 article.

The structure of Putnam's book is logical and direct. He first documents downward trends in civic involvement. He introduces and discusses several possible reasons for the decline. He argues that the decline has far-reaching negative effects, from destabilizing democratic institutions, to lowering the effectiveness of schools, to reducing the magnitude of powerful forces that improve collective health and well-being. He concludes with a call to action.

The book has three enormous attractions. It states a powerful and important thesis. It develops its argument in a broadly accessible way. It identifies and begins to exploit large data sets on social interactions. The scale of the thesis

\footnotetext{
${ }^{4}$ Bowling Alone. By Robert Putnam. 2000. New York: Simon \& Schuster. Pp. 544. ISBN 0-68483283-6. Social Capital: A Multifaceted Perspective. Edited by Partha Dasgupta and Ismail Serageldin. 1999. Washington, D.C.: The World Bank. Pp. xii, 424. ISBN 0-8213-4562-1.

5 Bowles (1999) and Lemann (1996) speculate on the reasons for the wide attention received by Putnam's work.
}

and the desire to reach a broad audience, however, leave the work open to criticism. Rhetoric often overwhelms logic. Passionate and repeated use of descriptive statistics often substitutes for detailed analysis.

Bowling Alone begins with a barrage of evidence that involvement in groups has been dropping in the United States over the past forty years. We are bowling alone and not in leagues. We are voting at lower rates. We belong to fewer clubs and participate in those we do belong to at lower rates. We are less likely to participate in organized religion. We are joining unions and professional organizations at lower rates. We are spending less time socializing. We donate less to charity (as a percentage of income). We trust our neighbors less. More of us are lawyers. Putnam provides more than enough data to convince even a skeptic that something is going on and that there may even be a common cause of the trend. This skeptical reader is convinced that something interesting is happening but unconvinced by the details of Putnam's argument. Let me briefly mention several reasons for concern.

The book often confuses cause and effect. The argument of the book appears to be that measurable declines in group activities cause bad outcomes. With this interpretation, reductions in monetary donations to charity may be seen as a consequence of a decline in social capital (provided a causal link can be established), but not as direct proof that the stock of social capital has decreased. ${ }^{6}$ Similarly, treating decreases in trusting behavior (as measured by survey responses) as direct evidence for decreases in social capital comes close to equating social capital with good outcomes.

\footnotetext{
${ }^{6}$ The book does not evaluate the hypothesis that declining contributions are a response to changes in the marginal tax rates.
} 
There is no analytical framework in which to evaluate the claim that the apparent trends are related. Technological and political forces that have played a major role in declining union membership rates may be unrelated to the factors leading to the near extinction of Elks clubs.

The book discusses and dismisses countertrends casually. Putnam argues that lobbying organizations like the Sierra Club and the American Association of Retired Persons are not substitutes for past membership organizations because they do not generate the levels of face-to-face interaction that clubs did fifty years ago. Nicholas Lemann (1996), who called his comment on Putnam (1995) "Kicking in Groups," mentions the rise in youth soccer, small businesses, and restaurants as countertrends ignored by Putnam (1995). ${ }^{7}$ Putnam argues that since work is about money it cannot be a way to build community, and he discounts social groups that form through workplace interactions.

Putnam has little to say about the internet and rightly so. He argues that the decline in community involvement began thirty or more years ago. The internet did not cause the decline in club membership. It is too early to say whether dot-community spirit can replace the old-fashioned kind.

Some technological change coincides with the interval of declining club membership. Putnam documents an increase in the number of households

\footnotetext{
${ }^{7}$ Putnam (2000, p. 459, note 16) does not ignore these issues in his book. He argues that the rise in youth soccer does not compensate for declines in other group athletic activities. He writes in a footnote that "none of the available evidence suggests that dining out has significantly increased over the last several decades" (yet this footnote begins "restaurant dinners rose from eighteen annually in 1975-76 to twenty-two in 1998-99 for married people").
}

with phones and long-distance phone calls made, but doubts that this growth does much to provide the social connections depleted when bowling leagues shrink. You cannot make friends using the telephone, he argues. But you can use the phone to maintain friendships. Putnam (p. 169) quotes Daniel Boorstin (1974), who writes that telephones permit "Americans to do more casually and with less effort what they had already been doing before," which suggests that phone calls are a plausible substitute for club meetings.

Telephones are an important example. Putnam invokes Ronald S. Burt's (2000) definition that you can measure a businessman's social capital by the size of his Rolodex. If the purpose of joining and participating in clubs is to expand connections-adding pages to the Rolodex-then changes in information technology that make it easier to get in touch with people reduce the need for participation in other ways.

Having presented the evidence of a decline in social capital, Putnam looks for the reasons. He allocates the largest share of the blame to generational differences, but he views increases in television viewing,, 8 commuting times, and female labor-market participation as significant factors in the decline of social capital. ${ }^{9}$

The most frustrating part of the book details the negative consequences of the decline in social capital. Putnam's measures of social capital are highly

\footnotetext{
8 Thomas Juster and Frank Stafford (1991, p. 475 ) point out that Japan has a higher rate of television viewing than the United States. Followers of Putnam who attempt to trace trends in Japanese civic involvement will want to keep this in mind.

${ }^{9}$ Dora Costa and Matthew Kahn (2001) perform a more careful investigation of the sources of the decline in social capital. Their study identifies income inequality and the rise in female laborforce participation as the most important factors explaining trends in social capital.
} 
correlated with good educational outcomes, good health, and good government. ${ }^{10}$ Some of these findings are reduced to formulas: "For North Carolina to see educational outcomes similar to Connecticut's, according to our statistical analysis, residents of the Tar Heel State could do any of the following: increase their turnout in presidential elections by 50 percent; double their frequency of club meeting attendance; triple the number of nonprofit organizations per thousand inhabitants; or attend church two more times per month" (p. 301) and "if one wanted to improve one's health, moving to a high-social capital state would do almost as much good as quitting smoking" (p. 328). The book's website (http://www.bowlingalone.com/) announces that "joining one group cuts in half your odds of dying next year." Putnam (2000, p. 334) does mention that the direction of causality has not been established, but most of the text takes the view that higher levels of certain social activities indirectly but inevitably lead to good outcomes.

Once Putnam has made his case that social capital is declining and that declining social capital has bad consequences, he presents a call for action. Deciding how best to reestablish social interactions requires a deeper understanding of where social capital comes from. Putnam switches between two opposing views. On one hand, there is the idea that patterns of civic involvement are deeply ingrained. He expresses this point of view strongly in an earlier book (Putnam, Leonardi, and Nanetti 1993)

\footnotetext{
${ }^{10}$ John Helliwell and Putnam's (1995) and Deepa Narayan and Lant Pritchett's (1999) contributions to the World Bank volume take a similar approach. Helliwell and Putnam show that measures of civic involvement are correlated with faster growth in Italian communities. Narayan and Pritchett demonstrate a relationship between measures of social capital, availability of credit, and adoption of new technologies in Tanzania.
}

that attributes the success of northern Italy relative to southern Italy to different social structures, which he traces back to the twelfth century. Maybe Americans are different from Italians, but even in Bowling Alone, he asserts that regional patterns of trust in the United States have long histories (p. 292) and argues that levels of civic involvement are relatively stable throughout an individual's lifetime. This view creates a problem. The hypothesis that levels of social capital change slowly demands that we reexamine the principal hypothesis of the book. Maybe Putnam neglected important sources of civic involvement after all. Otherwise we must believe that the environmental factors that led to changes in social capital were special and strong. This view makes efforts to reverse the trend seem unlikely to succeed.

The alternative point of view, which dominates the concluding sections of the book, is summarized by a quotation from Walter Lippmann (1961), which appears on page 379 and again on page 402. Lippmann writes "we have changed our environment more quickly than we have changed ourselves." When Lippmann wrote these words in 1914, people were already responding to changes in their era by inventing civic institutions that lasted throughout the twentieth century. We are to view the years following World War II as another era of great change. People who came of age in the sixties, with an incomplete understanding of the consequences of their behavior in a changing environment, devoted less time to civic activities. People now can see the error of their asocial ways and develop new civic organizations to meet the needs of a new century. Putnam (2000) ends his book by urging greater civic involvement "not because it will be good for America-though it will be-but 
because it will be good for us." The private returns to group participation should be sufficient to replenish our stock of social capital.

Putnam seems to say that individuals chose to deplete the collective stock of social capital because they miscalculated when the world changed. After they correct their mistake the trend can be reversed, thanks in large part to Putnam's advocacy. Even if current generations stick to their low levels of involvement, new generations, given the right encouragement, will act to reinvigorate public life. Another possibility is that choice behavior reveals preferences. Maybe people do not want to join groups. They can get jobs through the placement office at their school. They can find baby-sitters through want ads or friends at work. They get an adequate taste of politics listening to talk radio on their long commute. They prefer going to law school to making cupcakes for the PTA bake sale. They prefer an evening of "Must See TV" (which they can talk about the next day at the office) to the challenges of a card game or another long drive to the Elks Lodge. The jobs of social capital are getting done in other ways, and the price needed to maintain the past forms is just too high. ${ }^{11}$

Putnam ignores another interpretation, which is a natural one to economists. It is tempting to attribute variation in social and economic health of neighborhoods to coordination failures or multiple equilibrium problems. Social capital gives rise to positive externalities. If there are no clubs, then there are no clubs to join. Individual action is insufficient to increase social capital, and bad outcomes persist without selfless behavior or outside inter-

11 Michael Schudson (1998) makes the same point in his book on civic virtue. vention. According to this view, rapid social and technological changes were sufficient to lead young people (whose habits of social engagement were not fully formed) to become less active in community activities. Low levels of involvement today provide insufficient incentive for tomorrow's youth to have high civic involvement. The view that declines in levels of social capital represent a coordination failure provides a standard rationale for organized efforts to reestablish more efficient equilibria.

Bowling Alone contains a powerful thesis, extensive data, and rudimentary statistical analysis. It is an ambitious work, broadly accessible while touching on issues of interest to the political scientist, sociologist, social psychologist, and economist. Like Putnam's previous work on civic life in Italy, the research has already stimulated a huge number of follow-up studies. Few scholars have this impact. For those convinced by the book's arguments, Putnam has provided a passionate argument for renewing civic involvement. For those still skeptical, Putnam has provided a lifetime of research questions.

\section{Solow Strikes: Is Social Capital Capital?}

Bowling Alone explains the importance of community involvement to the health of democratic society in the United States. Economists find the social capital metaphor useful in studies of economic development, transition economies, common-resource property use, and education. Social Capital: A Multifaceted Perspective contains a collection of articles on aspects of social capital more commonly studied by economists. The book was completed in 1997 and draws on workshops held earlier in the nineties. It contains three previously published articles and 
several others that summarize ongoing research projects. While the book does provide a useful resource, particularly because it exposes contrasting intellectual frameworks underlying different uses of the term social capital, there is no reason to rush out and read (let alone buy) the book. Scholars new to the concept of social capital will not find a definitive synthesis or a straightforward introduction to the issues. ${ }^{12}$ Those interested in the frontiers of the subject can look at the web site maintained by the World Bank (http://www.worldbank.org/ poverty/scapital/), which provides a guide to the broad range of current research invoking the social capital metaphor.

Social Capital begins with brief introductory comments by two Nobel Prizewinning economists who argue that social capital is a poorly chosen name for the concept. In the thirteen articles that follow, at least nine contain extended discussion of what social capital means. One would have liked the editors to include a clear definition of the concept in the introduction to the book, and eliminate the need to define social capital repeatedly in the contributions. But this would have been impossible. No one could dispute that social capital is multifaceted. Authors recognize that if they are going to use the term, then they must define how they will use it.

The short articles by Kenneth Arrow (1999) and Robert Solow (1999) that begin the World Bank volume argue, in Solow's words, that social capital is "an attempt to gain conviction from a bad analogy." Arrow argues that physical capital has three characteristics: extension in time, deliberate sacrifice for

12 A single review essay cannot capture the many faces of social capital. Manski (2000) is a good introduction to the empirical problems in the study of social interactions. Portes (1998) and Woolcock (1998) are useful critical reviews of literatures from outside of economics. future benefit, and alienability. Social capital shares the temporal aspect of physical capital. Arrow argues that social capital does not require material sacrifice. While individuals do not invest directly in a commodity social capital (except in the model of Edward Glaeser, David Laibson, and Bruce Sacerdote 2000), they do often make calculated decisions to join clubs, do favors, and make and maintain relationships with an eye toward future benefits. Arrow was referring to aspects of social capital that are acquired without calculation or sacrifice. Children learn their first language without calculation. People are born into nobility and ethnicity. It is a stretch to view social capital derived from childhood friendships as a product of conscious calculation. It might be useful to distinguish between social capital that comes without sacrifice from that which is fixed. ${ }^{13}$ Nevertheless, the fraction of social capital that is costly to acquire seems significant enough to be worthy of study.

${ }^{13}$ Bourdieu (1986) introduced the notion of cultural capital in his paper on forms of capital. He measures cultural capital through educational qualifications, but his emphasis is on the ability of individuals to succeed in conventional educational settings. The concept originated "as a theoretical hypothesis which made it possible to explain the unequal scholastic achievement of children originating from the different social classes" (Bourdieu 1986, p. 243). Glenn Loury (1977 and 1987) uses the term social capital in a similar way in a similar context. George Borjas (1992) argues that an immigrant's ethnic capital, which he measures as the average human capital of co-ethnics, influences his ability to produce human capital. Your cultural capital includes your language, accent, manner, and familiarity with religious rituals. It is possible to modify your stock of cultural capital through deliberate action, but knowledge acquired in childhood, without calculation, severely constrains ability to acquire cultural capital. Using the term cultural capital to describe network attributes that one acquires without choice or sacrifice, and social capital to describe those attributes acquired purposefully (and, presumably, at a cost) would not be consistent with Bourdieu. He includes in the category of social capital titles and other connections that are not subject to choice. 
Arrow (1999) correctly asserts that one cannot transfer social capital from one person to another. ${ }^{14}$ To some extent, transfer is possible. Part of the social capital of a storeowner is the reputation of her shop. It is possible to transfer ownership of the shop without destroying the faith customers have in the products sold in the store. Indeed, one can imagine that establishing corporate identities and good names is a way to establish markets for certain types of social capital. ${ }^{15}$ Further, the criticism also applies, sometimes with greater power, to human capital. An individual need not destroy his own human capital when he transfers it (through teaching) to someone else.

Solow (1999) points out other differences between physical and social capital. He observes that physical capital has a rate of return and can be readily measured by summing past investment net of depreciation. Elinor Ostrom (1999) echoes these points (without rejecting the term social capital). Ostrom also observes that in contrast to physical capital, social capital appreciates with use. Traditional models of how the stock of physical capital changes with use give no insight into how to model the changes of social capital over time.

Arrow, Solow, and others convincingly point out the weaknesses of the analogy between physical capital and social capital. Efforts by James Coleman (1988), Glaeser, Laibson, and Sacerdote (2000), and Joseph Stiglitz (1999) to highlight the strengths of the analogy are not persuasive enough to justify the terminology. Careful scholars might follow Charles Manski's (2000) example and avoid the term social capital entirely. Yet contributions to the

\footnotetext{
14 Ákos Róna-Tas (nd) independently developed this idea.

15 See, for example, David Kreps (1990) and Steven Tadelis (1999).
}

World Bank volume provide convincing evidence that the topics under the social capital umbrella are worthy of study, and application of economic principles can provide important insights. A vague keyword is not sufficient reason to condemn a promising line of research. As Dasgupta (1999, p. 398) concludes, "social capital is useful insofar as it draws our attention to those particular institutions serving economic life that might otherwise go unnoted."

The World Bank volume responds to Arrow and Solow's discouraging introductory comments with a section of articles that provide insight into the conceptual foundations of social capital. The volume reprints Coleman's 1988 American Journal of Sociology article "Social Capital in the Creation of Human Capital." Several authors credit this article with bringing the concept of social capital to the attention of sociologists. Nearly all of the other papers in the World Bank volume cite this article (or Coleman 1990). Review articles ritualistically quote Coleman's definition of social capital. The contributions of the article are nicely observed stories of social interactions (particularly a discussion of wholesale diamond markets in New York City) and a discussion of the importance of network closure-dense connections between network participants-in maintaining trusting relationships. The actual definition of social capital offered by Coleman is unsatisfying. ${ }^{16}$ Coleman's article is published in a major journal and is readily available in libraries or JSTOR. Bourdieu's (1986) paper, which appeared in an obscure publication, would have been a more valuable contribution. An economist willing to endure a page of Gary Becker-bashing will find the coherent

\footnotetext{
${ }^{16}$ See Norman Uphoff (1999, p. 243), Foley and Edwards (1999, p. 144), Portes (1998, p. 5) for critiques.
} 
formulation of social and cultural capital that I used to begin this article. Bourdieu's approach is consistent with an economic (individual optimizing subject to constraints) view of social interactions.

Almost everyone who writes about social capital finds it necessary to provide some definition. Michael Foley and Bob Edwards (1999), Pamela Paxton (1999), Alejandro Portes (1998), Jonathan Turner (1999), and Michael Woolcock (1998) provide detailed critical reviews of broad literatures. These papers are not written for economists. Economists Samuel Bowles (1999) and Steven Durlauf (1999) provide brief, critical reviews of essential concepts. Manski's (2000) review essay focuses on empirical issues. One observation appears in most of these articles and deserves mention. Some authors, led by Coleman and Putnam, at times equate the existence of social capital with outcomes obtained using social capital. ${ }^{17}$ As Portes (1998) observes and Durlauf (1999) echoes, this equation leads to circular arguments: A successful group succeeded because it has social capital, but the evidence that the group has social capital is its success. This approach creates the impression that social capital must be good. The ability to use network relationships to obtain beneficial outcomes need not be good for society or even for the network. In many circumstances, these benefits come at a cost to individuals outside of the group. Society may lose when group members

17 Coleman (1988, p. S98) writes that "social capital is defined by its function" and presents examples suggesting that he interprets the definition broadly. Putnam puts forth many definitions of social capital, but one that clearly equates social capital with positive outcomes is quoted in Richard Rose (1999, p. 151): Putnam (1997, p. 31) defines social capital as "features of social life-networks, norms and trust-that facilitate cooperation and coordination for mutual benefit." exploit social capital. ${ }^{18}$ Arrow (1999), Durlauf (1999), and Portes (1998) make this point, which is acknowledged by Putnam (2000, ch. 22). Another potential negative feature of network interactions is that groups may coordinate on a bad equilibrium. An individual may be better off joining a group than staying out and being the target of attacks from the group, but the group may encourage risky or destructive behavior of its members, so that all group members would be better off if the group did not exist.

The World Bank volume concludes with a 100-page essay by coeditor Dasgupta (1999). This is an intelligent synthesis that connects ideas from repeated game theory and recent experimental work in economics to case studies in developing countries. Dasgupta suggests that the possibility that social capital directly enhances factor productivity provides a response to Solow's (1995) observation that it is hard to find evidence of social capital in crossnational studies of economic growth. Dasgupta ends his essay (and the volume) with a constructive (but not conclusive) discussion of problems measuring social capital.

\section{Institutions}

When people decide how to behave, they take into account the social, economic, and legal implications of their actions. These implications depend on the environment in which people make their choices. In this section, I will use the term institutional environment to describe the context in which decisions are made. Here I follow Lance Davis

18 When the prisoners in the prisoner's dilemma manage to cooperate, they receive a brief sentence. The prisoners are better off (relative to the equilibrium outcome), but presumably the rest of society, who are not included as strategic players, would prefer the criminals to remain in jail. 
and Douglass North (1971, p. 71), who define the institutional environment as "the set of fundamental political, social and legal ground rules that establish the basis for production, exchange and distribution." 19 From the perspective of game theory, it is convenient and tempting to view the institutional environment as specifying the "rules of the game" or the strategy sets of the players. This view is inadequate, since an individual's expectation of the response to his actions is often an important part of the institutional environment; that is, the institutional environment also serves to coordinate beliefs and select equilibria.

In this section I illustrate the proposition that the value and uses of social capital depend on the institutional environment. The general statement of this proposition is less meaningful than specific examples.

Goods and services provided through one form of social capital can be obtained through other mechanisms. Jane Jacobs (1961, p. 60), who was one of the first to use the term social capital, ${ }^{20}$ relates the story of the aptly named Joe Cornacchia. Joe runs a delicatessen near Jacobs's New York City home. He acts as a custodian for apartment keys. People in the neighborhood give Joe their keys with instructions to pass them to workers or friends who may need entry into the apartment. Jacobs says that "a service like this cannot be formalized. Identifications . . . questions ... insurance against mishaps. The all-essential line between public

19 Turner (1999, p. 97) gives an even broader definition, stating that the term institution "denotes the way that members of a population are organized in order to face fundamental problems of coordinating their activities to survive within a given environment."

${ }^{20}$ I found one only passing use of the term social capital (p. 138), but Jacobs's wonderful book is filled with examples of how a city's vitality depends on social bonds formed between neighbors. service and privacy would be transgressed by institutionalization. Nobody in his right mind would leave his key in such a place. The service must be given as a favor by someone with an unshakable understanding of the difference between a person's key and a person's private life, or it cannot be given at all" (ellipses in original).

Jacobs wrote about Joe Cornacchia forty years ago. By now the delicatessen has been replaced by The Gap. Jacobs's apartment building has a doorman who holds onto the keys. In the deli days, the neighborhood probably responded to Joe's service by purchasing regularly at his store and giving him gifts at Christmas. Now the rent may include money to pay the doorman's salary. The neighborhood changed when keys moved from the delicatessen's drawer to the doorman's safe. But the keystoring service can and has been formalized. They are many ways to solve a problem. Documenting a change does not document a crisis.

Ostrom (1999)'s contribution to the World Bank volume, which summarizes some of her remarkable work on common-property resources, highlights the importance of institutions. Ostrom and her collaborators (for example, Ostrom 1990 and Ostrom, Roy Gardner, and James Walker 1994) have studied irrigation projects in developing countries. Farmers need to work out arrangements that will permit them to build and maintain irrigation systems and share the water that these systems provide. These problems involve small numbers of agents who know each other and interact repeatedly. The theory of repeated games explains how selfinterested, calculating individuals can reach cooperative, efficient outcomes in this setting, but the same theory permits inefficient outcomes as well. Ostrom describes how farmers solve these 
problems and traces their solutions to the ability to construct commonly understood, commonly practiced, selfenforcing rules of behavior. The ability to do this is what Ostrom calls social capital. Ostrom demonstrates that these arrangements often take into account delicate balances of conflicting interests that are not transparent to outside observers, leading to the valuable lesson that external assistance, even when supplying enhanced technology, need not improve performance. Small communities develop different methods to solve collective-action problems. These methods can be placed in a general theoretical framework, but they require sensitivity to local conditions to work. Arrangements that enable people to put social connections to good work are local.

Ostrom's point is that sometimes groups are able to commit to an institution that provides a sensible way to govern the commons. We should be looking not only for the features of institutions that facilitate good outcomes, but how to arrive at these institutions, and what makes them stable. ${ }^{21}$

Studies of trust provide another example of the importance of institutions. Trust is the willingness to permit the decisions of others to influence your welfare. Levels of trust determine the

\footnotetext{
${ }^{21}$ Mary Brinton's (2000) study of the Japanese educational system provides a case study of an unstable institutional environment. Brinton observes that, until recently, students in Japanese secondary schools received job placements through their schools. Schools maintained long-term relationships with potential employers and had the power to match students to jobs. By virtue of this power, schools maintained control over students. Students behaved in order to receive attractive job placements. Brinton points out that the downturn of the Japanese economy and the changing characteristics of jobs available to low-skilled workers have eroded the school's importance as a source of jobs. The more the students can find jobs without the assistance of schools, the less control the schools have over students' behavior in school.
}

degree to which you are willing to extend credit or rely on the advice and actions of others. ${ }^{22}$ Several authors have constructed measures of trust and use these measures to search for correlation between trust and indicators of good economic performance. ${ }^{23}$

Trust depends on the institutional environment. Take the case of Japan. Toshio Yamagishi (1988) and his coauthors (Yamagishi, K. Cook, and M. Watabe 1998) argue that Japan exhibits low levels of trust in situations where mutual monitoring and sanctions do not exist. ${ }^{24}$ Yamagishi uses surveys to identify the level of trust, and then demonstrates that there is a link between survey responses and behavior in an experimental game. ${ }^{25}$ In contrast, Francis Fukuyama (1995) argues that intrinsic aspects of Japanese culture make the country exhibit high levels of trust, ${ }^{26}$ and that these high levels of trust translate into successful national performance. Solow (1995), who is skeptical

22 Oliver Williamson's (1993) narrow definition of trust would reserve the term for situations in which individuals completely ignore self-interest. In particular, according to Williamson an individual does not demonstrate trusting behavior if he gives up something today in expectation of a future return.

${ }^{23}$ Glaeser, Laibson, José Scheinkman, and Christine Soutter (2000), Stephen Knack and Philip Keefer (1997), and Rafael La Porta et al. (1997) are examples of this approach.

24 This view derives from classic ethnographic studies of Ruth Benedict (1946).

25 Survey data presented in Knack and Keefer (1997) and La Porta et al. (1997) indicate that general levels of trust are lower in Japan than in the United States. Nancy Buchan, Rachel Croson, and Robin Dawes's (1999) analysis of a variation of the trust game of Joyce Berg, John Dickhaut, and Kevin McCabe (1995) is consistent with Yamagishi's results.

${ }^{26}$ Fukuyama (1995, p. 205) summarizes the position: "Networks based on reciprocal moral obligation have ramified throughout the Japanese economy because the degree of generalized trust possible among unrelated people is extraordinarily high. . . Something in Japanese culture makes it very easy for one person to incur a reciprocal obligation to another and to maintain this obligation over extended periods of time." 
about the connection between trust and growth in general and Fukuyama's arguments in particular, appears to accept the assertion that Japan is a high-trust country.

Both high- and low-trust hypotheses could be consistent with observed behavior. Yamagishi (1988) argues that Japanese society provides (through social and culture rules that I refer to as an "institutional environment") a system of mutual monitoring that increases the level of trusting behavior. He represents this situation in the laboratory by performing an experiment. Yamagishi (1988) divided subjects into fourmember groups. Each member received fifty cents. Members then decided how much to contribute to other members of their group. Contributions were made simultaneously and secretly. The contributions of individual group members were doubled by the experimenter and divided equally between the other three members of the group. Yamagishi permitted the subjects to create an institutional environment that facilitates contributions by running experiments that also had a punishment condition. After deciding what to contribute, subjects decided how much to contribute to a punishment fund, to be paid out of cumulative earnings. The lowest contributor received a punishment equal to twice the total contribution to the punishment fund (if more than one person makes the lowest contribution, the lowest contributors paid equal shares of the punishment). When all four contributors contributed the maximum amount to the group, no one was punished. Yamagishi found that contributions in the no-sanction conditions were correlated to survey responses (so that people who were more trusting according to their survey responses contributed more to the group) and that subjects from the United States were more trusting and contributed at higher levels than Japanese. When subjects had the opportunity to create sanctions, less trusting individuals allocated more to the punishment fund than more trusting individuals, and the existence of the punishment fund generated higher contributions. Performance of groups of Japanese subjects, measured by their total earnings in the experiment, were increased when they had the ability to punish.

Simon Johnson, John McMillan, and Christopher Woodruff's (2000) study of courts and contracts in transition economies provides another view of how social capital must be viewed in the context of institutional stability. Johnson, McMillan, and Woodruff show that firms rely on relational contracting when they lack confidence in the ability of courts to enforce spot contracts. Trust, interpreted here as the willingness to extend credit, can arise either when firms have confidence in courts or when firms have an established relationship with their trading partner. Rachel Kranton's (1996) theoretical work is consistent with this observation.

These observations demonstrate how difficult it is to draw conclusions from cross-cultural comparisons of trust. The institutional and cultural frameworks that foster trust may be different in different countries. Controlling for these features may therefore have different implications in different settings.

Reconciling the different views on trust is important. Assuming a link between the ability to achieve trusting relationships and good outcomes, we would like to know whether the capacity to trust is based on deeply rooted cultural traditions (as suggested by Fukuyama 1995 and Putnam, Leonardi, and Nanetti 1993) or can be influenced by the kinds of institutions that can be constructed and nurtured in less than a generation. 


\section{Some Theoretical Questions}

I conclude this essay with some (game-)theoretical questions stimulated by a reflection on social capital.

\subsection{Appreciating Social Capital}

Ostrom (1999) points out that social capital need not depreciate with use the way physical capital does. In important instances, making use of social capital increases the stock of social capital available for future use. The anthropological literature on gift giving (M. Mauss 1990 is the traditional reference) discusses how offering a gift creates both an obligation to accept and an obligation to reciprocate. To the extent that using social capital operates like gift exchange, taking advantage of social capital creates an obligation to honor future requests for assistance and increases the value of an individual's connections.

If social capital facilitates efficient bargaining, say by inducing efficient outcomes in prisoner's dilemmas, exploiting social capital provides information that may make additional cooperation possible. Traditional game-theoretic analysis does not help describe this phenomenon. We know that it is equilibrium behavior to cooperate in a repeated prisoner's dilemma, but observing a history of cooperation does not make us more confident that there will be cooperation (or greater cooperation) in the future. Models of incomplete information help explain how bonds strengthen with use. Matthias Blonski and Daniel Probst (2000), Sobel (1985), and Joel Watson (1999) present models of the formation of trust. Through repeated interaction individuals learn whether their opponents have common interests. Successful experiences identify good partners and permit increases in the scale of exchange. In these mod- els the only reason that trust increases is that past experience is informative. Early investments therefore are costly because the trust may not be returned.

Incomplete information may capture another sense in which social capital increases through use. Elliot Aronson (1984, p. 287) explains how receiving a favor can strengthen a bond, as the donor must maintain good relations in order to receive a favor in exchange. The notion that owing someone a favor may be advantageous is counterintuitive, but is consistent with strategic models in which receiving a favor signals the availability of a compatible trading partner.

Once one accepts that successfully activating network connections, either to obtain benefits or to supply them, strengthens the bond between a pair of individuals, it is apparent that using social capital has positive third-party effects also. Expanding your network indirectly increases the social capital of your associates by giving them access to a larger network.

We know how to depreciate physical capital, but holding social capital to an analogous form of decay, as in Glaeser, Laibson, and Sacerdote (2000), is misleading. There is much to be learned from the development of models that show us how to appreciate social capital.

\subsection{Networks}

Social interactions depend on network structure. One would like to know, from a theoretical perspective, what kind of network performs best (for a given expenditure of network-creating effort) and what are the best locations within a network from an individual's perspective. Clear theoretical formulations of these questions may clarify issues in the sociological literature on networks.

An important insight from Coleman's work is the importance of network closure. Coleman argues that dense social 
networks make enforcement of group cooperative behavior more effective. This point can be interpreted in two ways. First, dense networks may act to create common knowledge of information, as in Michael Chwe (1999). Second, dense networks may increase the quality and reliability of third-party monitoring needed to enforce cooperative dynamic equilibria. The intuition behind the second observation is clear. Assume that good outcomes require sacrificing short-term material interest in the hope of receiving cooperative payoffs in the future (as in the repeated prisoner's dilemma) and that individuals play with different partners in different periods. Dense networks may facilitate good behavior by publicizing past actions and making it possible to punish noncooperative actions. To my knowledge, no one has formalized precisely this insight in a game-theoretic model, although the papers of Jonathan Bendor and Piotr Swistak (forthcoming) and Phillip Johnson, David Levine, and Wolfgang Pesendorfer (2001) provide two different possible approaches.

Ronald Burt (1992) emphasized the importance of structural holes for individuals in networks. An agent who connects two otherwise disconnected networks spans a structural hole. Burt (1992) documents that individuals who span structural holes earn additional rents from their position in the network. This position does not necessarily conflict with the network closure argument (although Burt 2001 argues that network closure has costs). The network closure view appears to concentrate on the average value of network investments, while the structural hole view concentrates on marginal values.

Mark Granovetter (1974) observed that people often locate jobs through weak or distant contacts. This insight superficially conflicts with Coleman's idea of network closure. One way to reduce the tension between the ideas is to realize that they apply to different problems. As Chwe (1999) observes, widely scattered weak links are better for obtaining information, while strong and dense links are better for collective action. People apply the notion of social capital to both types of situation. Knowing what types of network are best for generating social capital requires that one be specific about what the social capital is going to be used to do.

\subsection{Aggregation}

The most compelling work on social capital studies small group interactions. It is easier to trace the importance of social interactions in Jacobs's (1961) study of neighborhoods and Ostrom's (1999) studies of irrigation projects than studies that purport to link social capital with national trends. Studies that use data on trusting behavior or civic involvement to draw conclusions on regional or national development have little to say about the way in which one aggregates social capital across different networks. If one assumes that active networks solve coordination or collective action problems, then there is no puzzle. A small group's gain does not come at the expense of anyone else. To extend the metaphor to problems where the gains of network membership come in part at the expense of outsiders, one needs to provide a theory of how different networks overlap. Putnam (2000) provides useful terminology. He distinguishes between bonding and bridging social capital. The former provides denser networks and the latter creates larger networks. Putnam (2000) argues that it is bridging social capital that leads to a cohesive, well-functioning society. It remains to be seen how bridging social capital arises and creates positive outcomes in a strategic 
environment. Burt's (1992) work on structural holes indicates why individual agents have incentives to create links that enlarge networks. In Burt's environment, bridging social capital improves access to information and leads to improved outcomes for the group, even if the individual who fills the structural hole is most able to obtain these gains. On the other hand, more disperse networks mean (holding fixed the total investment in social connections) weaker networks. I am unaware of any theoretical work that identifies and evaluates these tradeoffs.

\subsection{Intrinsic Value of Group Membership}

The effectiveness of a particular kind of network depends on the institutions available. A responsive police force may protect my home from burglars as effectively as vigilant neighbors. Good neighbors make good fences, but burglar alarms may be a viable alternative. The social capital literature attempts to identify particular social conditions that lead to good economic outcomes. It indicates kinds of network interactions that appear to facilitate good outcomes. There is another point of view that is explicit in much of the descriptive literature on social capital. According to this view, developing social capital is good not only because it is associated with good economic performance. It is valuable intrinsically. If extensive use of community ties leads to the same economic performance as, say, strong legal rules, then society would be better off if the outcome came about through social networks. High voter turnout is desirable for its own sake even if it does not influence electoral outcomes. One can incorporate this position cheaply into economic models by assuming the social planners have preferences over institu- tions or behaviors that do not enter into individual preferences.

Simply assuming that it is impossible to identify social preferences by aggregating individual preferences does not do justice to observations like "joiners become more tolerant, less cynical, and more empathetic to the misfortunes of others" (Putnam 2000, p. 288), which suggest that social interactions actually change preferences. It does not do justice to the attention that the civic virtue literature pays to participation in the electoral process. ${ }^{27} \mathrm{~A}$ few theoretical papers, such as John Geanakoplos, David Pearce, and Ennio Stacchetti (1989) and Matthew Rabin (1993), provide ideas of how to model preferences that depend on the intentions of others. It is a challenge to apply these models to environments with network structures and to develop a framework for doing welfare analysis in models with changing preferences.

\section{REFERENCES}

Aronson, Elliot. 1984. The Social Animal. NY: W. H. Freeman.

Arrow, Kenneth J. 1999. "Observations on Social Capital," in Dasgupta and Serageldin, eds. op. cit., pp. 3-5.

Bendor, Jonathan and Piotr Swistak. Forthcoming. "The Evolution of Norms," Amer. J. Sociology.

Benedict, Ruth. 1946. The Chrysanthemum and the Sword: Patterns of Japanese Culture. Boston: Houghton Mifflin.

Berg, Joyce; John Dickhaut and Kevin McCabe. 1995. "Trust, Reciprocity and Social History," Games Econ. Behav. 10, pp. 122-42.

Blonski, Matthias and Daniel A. Probst. 2000. "The Emergence of Trust," Mannheim U. http://phoenix.vwi.unimannheim.de.

Borjas, George. 1992. "Ethnic Capital and Intergenerational Mobility." Quart. J. Econ. 107, pp. 123-50.

Boorstin, Daniel J. 1974. The Americans: The Democratic Experience. NY: Vintage Books.

Bourdieu, Pierre. 1986. "Forms of Capital," in Handbook of Theory and Research for the Sociology of Education. John G. Richardson, ed. Westport, CT: Greenwood Press, pp. 241-60.

27 Both Putnam (2000) and Schudson (1998) begin their monographs with tributes to voter turnout. 
Bowles, Samuel. 1999. "Social Capital' and Community Governance," Focus 20, pp. 6-10.

Brinton, Mary. 2000. "Social Capital in the Japanese Youth Labor Market: Labor Market Policy, Schools, and Norms," Policy Sciences 33:3-4, pp. 289-306.

Buchan, Nancy R.; Rachel T. A. Croson and Robyn M. Dawes. 1999. "Who's with Me? Direct and Indirect Trust and Reciprocity in China, Japan, Korea, and the United States," OPIM work. paper 00-08-01, Wharton School, U. Penn.

Burt, Ronald S. 1992. Structural Holes: The Social Structure of Competition. Cambridge: Harvard U. Press.

2000. "The Network Structure of Social Capital," in Research in Organizational Behavior, 22. Robert I. Sutton and Barry M. Staw, eds. Greenwich, CT: JAI Press. http://gsbwww. uchicago.edu/fac/ronald.burt/research/NSSC.pdf. 2001. "Bandwidth and Echo: Trust, Information, and Gossip in Social Networks," in Networks and Markets, Alessandra Casella and James E. Rauch, eds. Russell Sage Foundation.

Chwe, Michael Suk-Young. 1999." "Structure and Strategy in Collective Action," Amer. J. Sociology 105, pp. 128-56.

Coleman, James S. 1988. "Social Capital in the Creation of Human Capital," Amer. J. Sociology 94, pp. S95-S120. Reprinted in Dasgupta and Serageldin, eds. op. cit. pp. 13-39.

1990. Foundations of Social Theory. Cambridge: Harvard U. Press.

Costa, Dora L. and Matthew E. Kahn. 2001. "Understanding the Decline in Social Capital," NBER working paper 8295. http://www.nber. org/papers/w8295.

Dasgupta, Partha. 1999. "Economic Progress and the Idea of Social Capital," in Dasgupta and Serageldin, eds. op. cit. pp. 325-424.

Dasgupta, Partha and Ismail Serageldin, eds. 1999. Social Capital: A Multifaceted Perspective. Washington, DC: World Bank.

Davis, Lance and Douglass North. 1971. Institutional Change and American Economic Growth. NY: Cambridge U. Press.

Durlauf, Steven. 1999. "The Case 'Against' Social Capital," Focus 20, pp. 1-5.

Foley, Michael W. and Bob Edwards. 1999. "Is It Time to Disinvest in Social Capital?" J. Public Pol. 19:2, pp. 141-73.

Fukuyama, Francis. 1995. Trust. NY: Free Press.

Geanakoplos, John; David Pearce and Ennio Stacchetti. 1989. "Psychological Games and Sequential Rationality," Games Econ. Behav. 1, pp. $60-79$.

Glaeser, Edward; David Laibson and Bruce Sacerdote. 2000. "The Economic Approach to Social Capital," NBER working paper 7728. http:// papers.nber.org/papers/W7728.

Glaeser, Edward; David Laibson, José Scheinkman and Christine Soutter. 2000 "Measuring Trust," Quart. J. Econ. 115, pp. 811-41.

Granovetter, Mark S. 1974. Getting a Job: A Study of Contacts and Careers. Chicago: U. Chicago Press.

Helliwell, John F. and Robert D. Putnam. 1995. "Economic Growth and Social Capital in Italy," Eastern Econ. J. 21. Reprinted in Dasgupta and Serageldin, eds. op. cit. pp. 253-68.

Jacobs, Jane. 1961. The Death and Life of Great American Cities. NY: Random House.

Johnson, Phillip; David K. Levine and Wolfgang Pesendorfer. 2001. "Evolution and Information in a Gift-Giving Game," J. Econ. Theory, forthcoming.

Johnson, Simon; John McMillan and Christopher Woodruff. 2002. "Courts and Relational Contracts," J. Law, Econ., Org. 18:1, forthcoming.

Juster, F. Thomas and Frank D. Stafford. 1991. "The Allocation of Time: Empirical Findings, Behavioral Models, and Problems of Measurement," J. Econ. Lit. 29, pp. 471-522.

Knack, Stephen and Philip Keefer. 1997. "Does Social Capital Have an Economic Payoff?" Quart. J. Econ. 112, pp. 1251-88.

Kranton, Rachel. 1996. "Reciprocal Exchange: A Self-Sustaining System." Amer. Econ. Rev. 86, pp. 830-51.

Kreps, David M. 1990. "Corporate Culture and Economic Theory," in Perspectives on Positive Political Economy. James E. Alt and Kenneth A. Shepsle, eds. NY: Cambridge U. Press, pp. 90143.

La Porta, Rafael; Florencio Lopez-de-Silanes, Andrei Shleifer and Robert W. Vishny. 1997. "Trust in Large Organizations," Amer. Econ. Rev. Pap. Proceedings 87, pp. 333-38. Reprinted in Dasgupta and Serageldin, eds. op. cit. pp. 253-68.

Lemann, Nicholas. 1996. "Kicking in Groups," Atlantic Monthly, 277, April, pp. 22-26.

Lippmann, Walter. 1961 (1914). Drift and Mastery. Englewood Cliffs, NJ: Prentice-Hall.

Loury, Glenn C. 1977. "A Dynamic Theory of Racial Income Differences," in Women, Minorities, and Employment Discrimination. Phyllis Wallace and Annette M. La Mond, eds. Lexington, MA: Heath, pp. 153-86. 1987. "Why Should We Care about Group Inequality?" Social Phil. Pol. 5:1, pp. 249-71.

Manski, Charles. 2000. "Economic Analysis of Social Interactions," J. Econ. Perspect. 14, pp. 115-36.

Mauss, M. 1990. The Gift: The Form and Reason for Exchange in Archaic Societies. London: Routledge.

Narayan, Deepa and Lant Pritchett. 1999. "Social Capital: Evidence and Implications," in Dasgupta and Serageldin, eds. op. cit. pp. 26995.

Ostrom, Elinor. 1990. Governing the Commons: The Evolution of Institutions for Collective Action. Cambridge: Cambridge U. Press.

1999. "Social Capital: A Fad or a Fundamental Concept," in Dasgupta and Serageldin, eds. op. cit. pp. 172-214.

Ostrom, Elinor; Roy Gardner and James Walker. 
1994. Rules, Games, and Common-Pool Resources. Ann Arbor: U. Michigan Press.

Paxton, Pamela. 1999. "Is Social Capital Declining in the United States? A Multiple Indicator Assessment," Amer. J. Sociology 105, pp. 88-127.

Portes, Alejandro. 1998. "Social Capital: Its Origins and Applications in Modern Sociology," Annual Rev. Sociology 24, pp. 1-24.

Putnam, Robert (with Robert Leonardi and Raffaella Nanetti). 1993. Making Democracy Work. Princeton: Princeton U. Press.

Putnam, Robert. 1995. "Bowling Alone: America's Declining Social Capital," J. Democracy 6, pp. 65-78.

1997. "Democracy in America at Century's End" in Democracy's Victory and Crisis. Axel Hadenius, ed. NY: Cambridge U. Press, pp. 27-70. 2000. Bowling Alone: The Collapse and Revival of American Community. NY: Simon and Schuster.

Rabin, Matthew. 1993. "Incorporating Fairness into Game Theory," Amer. Econ. Rev. 83, pp. 1281302.

Róna-Tas, Ákos. (nd: 1998?). "Path-Dependence and Capital Theory: Sociology of the PostCommunist Economic Transformation," in Szelényi60. Éva Fodor and János Ladányi, eds. http://hi.rutgers.edu/szelenyi60/, http://hi.rutgers.edu/szelenyi60/rona-tas.html.

Rose, Richard. 1999. "Getting Things Done in an Antimodern Society: Social Capital Networks in Russia," in Dasgupta and Serageldin, eds. op. cit. pp. 147-71.

Schudson, Michael. 1998. The Good Citizen. NY: Free Press.

Stiglitz, Joseph E. 1999. "Formal and Informal
Institutions," in Dasgupta and Serageldin, eds. op. cit. pp. 59-68.

Sobel, Joel. 1985. "A Theory of Credibility," Rev. Econ. Stud. 52, pp. 557-73.

Solow, Robert M. 1995. "But Verify," The New Republic, Sept. 11, pp. 36-39.

. 1999. "Notes on Social Capital and Economic Performance," in Dasgupta and Serageldin, eds. op. cit. pp. 6-10.

Tadelis, Steven. 1999. "What's in a Name? Reputation as a Tradeable Asset," Amer. Econ. Rev. 89 , pp. 548-63.

Tocqueville, Alexis de. 1945. Democracy in America. NY: Alfred A. Knopf.

Turner, Jonathan H. 1999. "The Formation of Social Capital," in Dasgupta and Serageldin, eds. op. cit. pp. 94-146.

Uphoff, Norman. 1999. "Understanding Social Capital: Learning from the Analysis and Experience of Participation," in Dasgupta and Serageldin, eds. op. cit. pp. 215-49.

Watson, Joel. 1999. "Starting Small and Renegotiation," J. Econ. Theory 85, pp. 52-90.

Williamson, Oliver E. 1993. "Calculativeness, Trust, and Economic Organization," J. Law Econ. 36, pp. 453-86.

Woolcock, Michael. 1998. "Social Capital and Economic Development," Theory and Society 27, pp. 151-208.

Yamagishi, Toshio. 1988. "The Provision of a Sanctioning System in the United States and Japan," Social Psych. Quart. 51:3, pp. 265-71.

Yamagishi, Toshio; K. Cook and M. Watabe. 1998. "Uncertainty, Trust, and Commitment Formation in the United States and Japan," Amer. J. Sociology 104, pp. 165-94. 